\title{
Composition of the Food of Martens ${ }^{1}$
}

\author{
Jacek GOSZCZYŃSKI ${ }^{2}$
}

\begin{abstract}
Goszczyński J., 1976: Composition of the food of martens. Acta theriol., 21, 36: 527-534 [With 4 Tables \& 1 Fig.].

The diet of martens (Martes sp.) was examined by means of analysis of 835 excrements. Fruits $(42.7 \%)$, small rodents $(32.4 \%)$, birds $(15.7 \%)$, Lagomorpha $(5.3 \%)$ and insects form the main components of food biomass. During the summer-autumn period the diet of martens consists chiefly of plant food, and in winter and spring animal food. The role of martens in reduction of voles, hares and game birds is discussed.

[Inst. Ecol., Dept. Agroecol., 64-003 Turew, Poland].
\end{abstract}

\section{INTRODUCTION}

Studies were carried out from 1969-74 in the Laboratory of Agroecology, Polish Academy of Sciences at Turew on the role of predators in the biocenoses of cultivated fields (Ryszkowski, Wagner, Goszczyński \& Truszkowski, 1971; Goszczyński, 1972; Ryszkowski, Goszczyński \& Truszkowski, 1973; Goszczyński, 1974; Truszkowski, 1975), including in these studies two species of marten: Martes martes (L in n a u s, 1758) and Martes foina (Erxleben, 1777) occurring in the Turew district. By estimating the composition of food consumed by martens it proved possible to define the: $r$ position in the group of predatory birds and mammals analysed.

\section{STUDY AREA}

Studies were carried out over an area of $31 \mathrm{~km}^{2}$ in the Turew district $\left(52^{\circ} 04^{\prime} \mathrm{N}\right.$, $16^{\circ} 48^{\prime} \mathrm{E}$ ). Tree stands, shelterbelts and parks cover approx. $12 \%$ of the area. The hollowed trees which occur fairly frequently in the woods and parks there provicle suitable conditions for the martens to shelter and rear their young. Cultivated fields decidedly predominate in the study area, and are usually sown with winter cereals, spring plants and root crops. The small woods (up to $1 \mathrm{~km}^{2}$ ) are connected by numerous shelterbelts which enable the martens to move from place to place even during the day. A more detailed description of the area is to be found in the study by Ryskowski et al. (1973).

1 Praca została wykonana $w$ ramach problemu węzłowego 09.1.7., koordynowanego przez Instytut Ekologii PAN.

2 Present address: Inst. Kształtowania Środowiska, 02-078 Warszawa, Krzywickiego 9. 


\section{METHODS}

Analysis of 835 excrements has been used to ascertain the martens' diet. As it proved impossible to distinguish between Martes martes and Martes foina on the basis of their faeces these two species have been treated jointly. Portions of excrement collected during one season were segregated under a binocular microscope into the various components, and the separated parts rinsed in sieves and dried under radiators. The method described by Lockie (1959 and 1961) and Goszczyński (1974) were used to determine the percentages formed by the various components in the animals' diet, consisting in multiplying the dry weight of the material separated from the faeces by the digestibility coefficient ${ }^{3}$ of this material. This permits of cstimating the biomass of the food components and the percentage they form in the animals' diet. The degree to which the various food components are digested by foxes and martens is similar (L o ckie, 1961), and therefore coefficients of digestibility of different foods estimated in nutrition tests on foxes can be used to evaluate the diet of martens. In order to estimate the biomass of hares eaten by martens the coefficient of digestibility was taken as $\mathbf{5 0}$, for small rodents 23 , for birds 35 , and for roe deer 118 , after the study by Goszczyński (1974), and for fruits and insects the coefficients 14 and 5 given in the study by Lockie (1961). In the case of insectivores (shrews, moles, hedgehogs) and squirrels the digestibility coefficient was taken as 23 , that is, the same as for small rodents. The participation of different species in the class of small rodents was estimated on the basis of identification of teeth.

Supplementary information on birds eaten by martens was obtained by observing tracks in winter.

\section{COMPOSITION OF THE FOOD OF MARTENS}

\subsection{Small Rodents}

Small rodents form a constant component of the food of martens and their participation in the diet of these predators reached its highest level from 1971-72 (Fig. 1a). In the summer and autumn of 1971 there was an irruption of Microtus arvalis ( $\mathrm{Pallas}$, 1779) in the study area and in winter and spring of the following year the density of this rodent was still maintained on a high level (R y s z k o w s k i et al., 1973). During this period the vole decidedly predominated among the rodents caught by martens (Fig. 1a). In the other years martens more often caught mice of the genus Apodemus and the bank vole Clethrionomys glareolus ( $\mathrm{S} \mathrm{chreber}, 1780$ ). House mice, harvest mice and root voles are very seldom caught by martens (Table 1 ).

\subsection{Roe deer and Lagomorpha}

Martens ate only small amounts of this type of food (Table 1 and Fig. $1 b)$, chiefly in winter and spring. They probably eat only dead indi-

\footnotetext{
Soefficient of digestibility $=$ relation between weight of consumed food and weight of undigested remnants.
} 
Table 1

Composition of the martens diet (1969-1974), as expressed in percentages of biomass.

\begin{tabular}{|c|c|c|c|c|}
\hline Type of food & Winter & Spring & $\begin{array}{l}\text { Summer } \\
\text { Autumn }\end{array}$ & $\begin{array}{c}\text { Whole } \\
\text { year }\end{array}$ \\
\hline Microtus arvalis & 29.8 & 24.0 & 22.3 & 24.6 \\
\hline $\begin{array}{l}\text { Apodemus sp., Clethrionomys glareolus } \\
\text { Mus musculus, Micromys minutus, }\end{array}$ & 8.8 & 16.3 & 1.9 & 7.2 \\
\hline Microtus oeconomus & 1.3 & 0.6 & 0.3 & 0.6 \\
\hline Total small rodents & 39.9 & 40.9 & 24.5 & 32.4 \\
\hline Lagomorpha & 10.7 & 7.4 & 1.5 & 5.3 \\
\hline Capreolus capreolus & 3.0 & 1.8 & 0.0 & 1.2 \\
\hline Sciurus vulgaris & 0.3 & 1.4 & 0.0 & 0.4 \\
\hline Talpa europea & 0.6 & 0.3 & 0.0 & 0.2 \\
\hline Erinaceus europaeus & 0.3 & 0.0 & 0.0 & 0.1 \\
\hline Soricidae & 0.2 & 0.8 & 0.1 & 0.3 \\
\hline Aves & 16.7 & 41.0 & 2.5 & 15.7 \\
\hline Insecta & 0.1 & 5.2 & 0.8 & 1.7 \\
\hline Plants & 28.2 & 1.2 & 70.6 & 42.7 \\
\hline Total & 100.0 & 100.0 & 100.0 & 100.0 \\
\hline
\end{tabular}

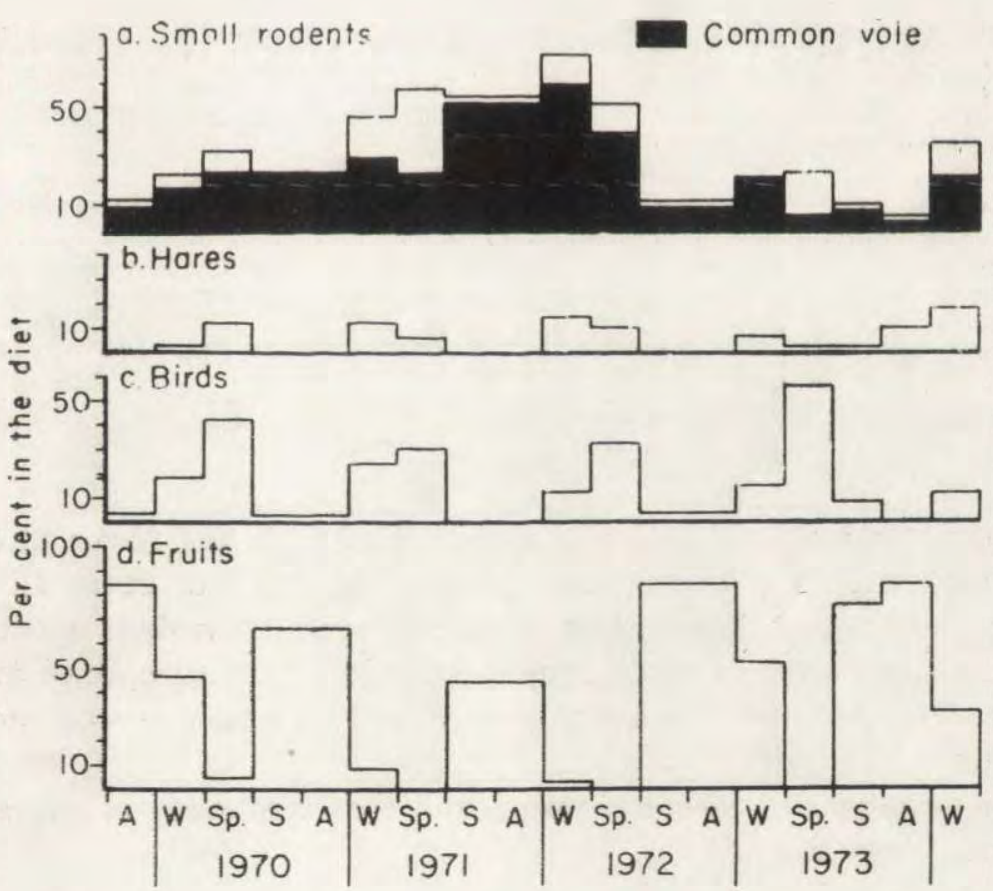

Fig. 1. Seasonal representations of the major food groups in the martens diet. $\mathrm{W}$ - winter, Sp - spring, S - summer, A - autumn. 
viduals of Capreolus capreolus ( $\mathrm{L}$ in n a e us, 1758), as is shown by the results of winter tracking operations carried out in 1970-71.

Although the rabbit Oryctolagus cuniculus (L innale us, 1758) also occurs in the study area, the hare Lepus europaeus (P a $11 \mathrm{a}, \mathrm{s}, 1778$ ) decidedly predominates. It would therefore appear that the majority of Lagomorpha consumed by martens are hares.

\subsection{Birds}

Birds are caught chiefly in winter and spring and their participation in the diet of martens depends on the abundance of voles. From 197172 when the density of voles was high and the percentage formed by

\section{Table 2}

Birds consumed by the martens (material from winter tracking and collected around nests).

\begin{tabular}{|c|c|c|c|c|}
\hline Species & $\begin{array}{c}\text { No.of } \\
\text { individuals }\end{array}$ & $\begin{array}{c}\text { Mean wt. } \\
\mathrm{g}\end{array}$ & $\begin{array}{c}\text { Consumed } \\
\text { biomass, } \\
\text { g }\end{array}$ & $\begin{array}{l}\text { Per cent } \\
\text { of biomass }\end{array}$ \\
\hline Gallus domesticus & 2 & 1600 & 3200 & 49.3 \\
\hline Phasianus colchicus & 1 & 1200 & 1200 & 18.5 \\
\hline Perdix perdix & 3 & 430 & 1290 & 19.9 \\
\hline Corvus frugilegus & 1 & 300 & 300 & 4.6 \\
\hline Garrulus glandaris & 1 & 170 & 170 & 2.6 \\
\hline Turdus merula & $1 \leqslant$ & 96 & 96 & 1.5 \\
\hline Dryobates major & $1.45=$ & 85 & 85 & 1.3 \\
\hline Pyrrhula pyrrhula & 1 & 30 & 30 & 0.5 \\
\hline Fringillidae & 1 & 25 & 25 & 0.4 \\
\hline Emberiza sp. & 1 & 25 & 25 & 0.4 \\
\hline Parus major & 2 & 20 & 40 & 0.6 \\
\hline Parus careulus & 2 & 12 & 24 & 0.4 \\
\hline Aegithalos caudatus. & 1 & 9 & 9 & 0.1 \\
\hline Total & & & 6494 & 100.1 \\
\hline
\end{tabular}

this rodent in martens' diet was as much as $50 \%$, far fewer birds were eaten by martens than in other years (Fig. 1c and Table 1). Among species caught in winter hens, pheasants and partridges form almost $90 \%$ of the biomass of birds caught (Table 2). Small species are more often caught, but taken altogether form only a small percentage of the total number of birds (Table 2).

During analysis of faeces it was found that frequency of egg shells in excrement was approx. $2 \%$.

\subsection{Fruits}

During the summer-autumn period the percentage formed by fruits in the diet of martens was as much as $70 \%$ (Table 1). When there is 
a deficiency of animal food martens consume a considerable amount of fruits in winter also (Fig. 1d), apples, pears and plums being eaten in the greatest amounts (Table 3). In winter martens take apples and pears lying on the ground under trees or consume hips and haws still remaining on bushes (Table 3 ).

\subsection{Other Food}

Insectivores and squirrels form food consumed at random by martens in the study are (in all up to $1 \%$ by weight) (Table 1 ). Insects are eaten chiefly in spring (Table 1). Melolontha, Geotrupes and Vespidae predominate among the insects eaten by martens.

Table 3

Fruits in the diet of martens (percentage by weight).

\begin{tabular}{lcc}
\hline \multirow{2}{*}{ Kind of fruits } & \multicolumn{2}{c}{ Season } \\
\cline { 2 - 3 } & Summer-Autumn & Winter \\
\hline Prunus avium and $P$. cerasus & 14.8 & 0.0 \\
Padus serotina & 6.3 & 0.0 \\
Prunus domestica & 25.7 & 1.0 \\
Prunus spinosa & 3.1 & 0.0 \\
Malus domestica & 6.6 & 43.6 \\
Pirus sp. & 25.7 & 23.3 \\
Rubus caesius & 7.3 & 0.0 \\
Rosa canina & 5.0 & 21.6 \\
Crataegus sp. & 3.5 & 10.5 \\
Sorbus aucuparia & 2.0 & 0.0 \\
Tótal & 100.0 & 100.0 \\
\hline
\end{tabular}

6. DISCUSSION

The data presented in this study show clearly that the diet of martens is of a polyphagous character. These predators use plant and animal food to an approximately equal degree. In spring and summer they eat chiefly animal food, but in summer and autumn fruits clearly predominate in the diet of these animals. Shelterbelts and wayside tree stands often contain hawthorn, wild rose, black currant and cherries, and one of the largest orchards in the Turew district is bordered by a wood, which makes it easier for martens to obtain fruit. The clearly defined seasonal character of consumption of firuit and the high percentage they form (up to $50^{\%} \%$ ) in the marten's diet has also been emphasised by Lockie (1961).

Throughout the whole study period small rodents formed a constant component of the food of these animals. Changes in the percentage of 
small rodents in martens' diet depend on abundance of voles, which are most often caught by these predators. With high densities of voles martens eat fruit less often and less often catch birds. The degree to which use is made of these foods is thus modified by the number of rodents in fields. The vole does not, however, play so important a part in the marten's diet as in that of the fox (Goszczyns ki, 1974), the

\section{Table 4}

Percentage formed by certain components of the diet of martens in the Soviet Union (frequency of occurrence)

\begin{tabular}{|c|c|c|c|c|c|c|c|}
\hline $\begin{array}{l}\text { Ref. } \\
\text { No. }\end{array}$ & $\begin{array}{c}\text { Small } \\
\text { rodents }\end{array}$ & Lagomorpha & Squirrels & Birds & Insectivora & Insects & $\begin{array}{l}\text { Plant } \\
\text { food }\end{array}$ \\
\hline \multicolumn{8}{|c|}{ Martes martes } \\
\hline 1 & 58.4 & 5.4 & 14.1 & 12.8 & & 3.4 & 21.6 \\
\hline 2 & & 6.8 & 11.1 & 30.4 & & 13.4 & 0.6 \\
\hline 3 & 56.0 & 1.7 & 7.3 & 24.3 & 5.3 & 11.0 & 10.3 \\
\hline 4 & 50.0 & 4.0 & 3.0 & 15.0 & 29.0 & 13.0 & 10.0 \\
\hline 5 & 73.0 & 5.0 & 6.0 & 0.0 & 0.0 & 4.0 & 7.0 \\
\hline 6 & & & 1.8 & & & 6.0 & \\
\hline 7 & 38.6 & 13.7 & 6.8 & & 24.4 & 1.0 & \\
\hline 8 & 58.3 & 5.5 & 9.0 & & 11.7 & 5.5 & \\
\hline 9 & 40.3 & & 3.8 & & 6.2 & & \\
\hline 10 & 37.8 & & 6.0 & & 0.0 & 25.4 & \\
\hline 11 & 71.2 & & 1.0 & & 5.1 & 24.2 & \\
\hline 12 & $42.0-58.0$ & $4.0-15.0$ & $4.0-12.0$ & $24.0-46.0$ & $5.0-18.0$ & & $1.0-10.0$ \\
\hline 13 & 52.0 & 5.6 & 21.2 & 32.6 & 2.8 & 27.7 & \\
\hline 14 & 53.8 & 0.2 & & 15.1 & & 23.5 & 35.0 \\
\hline 15 & 72.0 & $4.3-5.8$ & 9.3 & 4.0 & 0.0 & 24.0 & 14.6 \\
\hline 16 & 45.1 & 5.0 & 7.1 & 21.5 & 6.1 & & \\
\hline 17 & 49.0 & & & 18.0 & & 22.0 & 44.0 \\
\hline \multicolumn{8}{|c|}{ Martes foina } \\
\hline 18 & 21.5 & 1.7 & 0.1 & 34.4 & 2.6 & 34.1 & 61.5 \\
\hline 19 & 38.5 & 0.9 & & 38.7 & & 36.7 & 50.0 \\
\hline 20 & 41.0 & 1.3 & 0.0 & 16.0 & & 50.4 & \\
\hline 21 & 55.6 & 13.8 & & 44.6 & & 50.4 & 62.3 \\
\hline 22 & 7.0 & & & 3.0 & & , & \\
\hline \multicolumn{8}{|c|}{ Martes sp. } \\
\hline 23 & 70.0 & 1.1 & 5.0 & 19.9 & 0.5 & 13.5 & 70.5 \\
\hline
\end{tabular}

No. $1-14$ and $18-19$ after $\mathrm{N}$ a simovi č (1973), No. 15-16 and $20-22$ after $\mathrm{He} \mathrm{pt-}$ ner et al., (1967), No. 17 after Korčmer (1969), No. 23 after Gas he v (1965).

buzzard (Truszkowski, 1975) the long-eared and barn owls (Ryszk owski et al. 1973). Marten's reduce about 3 per cent of the vole population, whereas the participation of these predators in reduction of mice of the genus Apodemus and the bank vole is as much as $11 \%$ (R y s'zkowski et al. 1973). The results given in literature and set out in Table 4, although grouping data obtained by a different method (fre- 
quency in faeces or stomachs) even so confirm the importance of small rodents in the diet of martens.

The participation of Lagomorpha in marten's food is low in the study area, and also in areas in the USSR (Table 4). In Scotland hares and rabbits form from 0 to $33 \%$ (average about $6 \%$ ) of the diet of Martes martes ( $\mathrm{Lockie}, 1961$ ), whereas in Poland this figure, as estimated by $\mathrm{Rz}$ ebik-Kowalska (1972), is $7.5 \%$. The participation of birds (including game birds) is far higher (Table 4). In the spring of 1973 birds formed more than half of the food consumed by martens in the Turew district. In view of the low numbers of these predators $(0.2-0.4$ individuals $/ \mathrm{km}^{2}-\mathrm{Ryszkowski}$ et al. 1973 ) and the fact that part of their food consists probably of carion, these predators do not play a significat part in reduction of hares and game birds. Martens may exert an indirect effect on the numbers of birds by destroying their eggs, but the method used in this study made it impossible to estimate the extent of this phenomenon.

Only small numbers of insectivores and squirrels are consumed (Table 4), although more often elsewhere than in the study area. Also, according to data given by $\mathrm{R} \mathrm{ze} \mathrm{bik-Kow} \mathrm{a} 1 \mathrm{sk}$ a (1972) insectivores and squirrels form respectively 9.4 and $13.4 \%$ in the predators' diet, showing that frequent use is made of this food. The causes of this phenomenon must be considered as probably lying in the typically agricultural character of the Turew district (meadows and forests being biotopes preferred by shrews, moles and squirrels forming only a small percentage of the whole of the study area).

The data given in table 4 on frequency of occurrence of insects in the predators' diet do not reflect the importance of this food to martens. Although insects are often found in excrement, they form a food component of little significance (L o c k i e, 1961).

Acknowledgments: My thanks are due to Dr. hab. K. Dobrowolski, Dr. Z. B ogucki and J. Truszkowski, M. Sc. for identifying the species of birds.

\section{REFERENCES}

1. G a shev N. S., 1965: Pitanije kunnyh roda Martes na Severnom Urale. Biul. MOIP, 70, 3: 16-22.

2. Goszczyński J., 1972: Wpływ drapieżników na populację nornika zwy.czajnego (Microtus arvalis). Inst. Ecol. PAN, Zeszyty naukowe, 5: 301-309.

3. Goszczyński J., 1974: Studies on the food of foxes. Acta theriol., 19, 1: $1-18$.

4. Heptner V. G., Naumov N. P., Jurgenson P. B., Sludskij A. A, Cirkova A. F. \& Bannikov A. G., 1967: Mlekopitajuščije Sovetskogo Sojuza. Vyssaja Škola, 2: 1-1004. Moskva. 
5. K or čmar N. D., 1969: Lesnaja kunica v Moldavii. Voprosy ekol. i prakt. značenija ptic i mlekopitajuščih w Moldavii, 3: 80-86.

6. L o ckie J. D., 1959: The estimation of the food of foxes. J. Wildl. Manage, 23, 2: $224-227$.

7. Lockie J. D., 1961: The food of the pine marten Martes martes in West Ross-Shire, Scotland. Proc. zool. Soc., Lond., 136: 187-195.

8. Nasimovič A. A. (Ed.), 1973: Sobol, kunicy, harza. Razmeščenie zapasov, ekologija, ispol'zovanie i ohrana. Nauka: 1-240. Moskva.

9. Ryszkowski L., Wagner C. K., Goszczyński J. \& Truszkowski J., 1971: Operation of predators in a forest and cultivated fields. Ann. Zool. Fennici, 8: 160-169.

10. Ryszkowski L., Goszczyński J. \& Truszkowski J., 1973: Trophic relationships of the common vole in cultivated fields. Acta theriol., 18, 7: $125-165$.

11. Rzebik-Kowalska B., 1972: Badania nad pokarmem ssaków drapieżnych w Polsce. Acta zool. Cracovensia, 17, 19: 415-506.

12. Truszkowski J., 1976: Próba oceny roli myszołowa w-agrocenozach Srodkowej Wielkopolski. Pol. ecol. Stud.

Accepted, April 2, 1976

Jacek GOSZCZYŃSKI

\section{BADANIA NAD POKARMEM KUN}

\section{Streszczenie}

Dietę kun (Martes sp.) zestawiono na podstawie analiz 835 ekskrementów. Zimą i wiosną w diecie przeważa pokarm zwierzęcy, a latem i jesienią - owoce (Tabela 1 i Ryc. 1 d). Owoce głównie jabłka, gruszki, śliwki, głóg i dzika róża (Tabela 3) stanowią wagowo w pokarmie $42,7 \%$. Drobne gryzonie są składnikiem pokarmu wykorzystywanym przez cały rok (Ryc. 1 a). Wśród nich najważniejszym gatunkiem jest nornik zwyczajny. Przy wysokich stanach nornika kuny rzadziej jedzą ptaki i owoce. Przeciętny udział ptaków i zajęcy w diecie kun wynosi odpowiednio 15,7 i $5,3 \%$. W okresie zimowym wśród ptaków przeważają kury, bażanty i kuropatwy (Tabela 2). Zebrane dane wskazują na polifagiczny charakter diety kun 